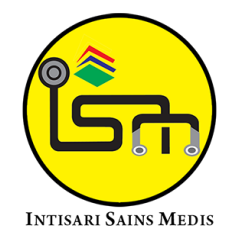

Published by Intisari Sains Medis

\title{
Sifilis sekunder pada seorang remaja perempuan: laporan kasus
}

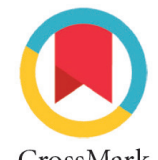

CrossMark

\author{
Ida Ayu Uttari Priyadarshini ${ }^{1 *}$, Elice Wijaya ${ }^{1}$, Ni Made Dwi Puspawati ${ }^{2}$
}

\begin{abstract}
Introduction: Syphilis is one of the most common sexually transmitted infections worldwide. Syphilis can be acute to chronic. Syphilis is caused by the parasite Treponema pallidum (T. pallidum). Transmitted through sexual contact and blood. In this case, we report a case of secondary syphilis in an adolescent girl.

Case report: an 18-year-old girl came with complaints of red spots on the palms of the hands and soles of the feet, with a history of sores in the pubic area that were painless and odorless and then healed on their own so no treatment was given. A history of positive sexual contact approximately one week before the patient came for examination. On dermatological status, right and left palmar and plantar locations found erythematous macules, round to geographical in shape with diameters of $0.5 \mathrm{~cm}-1.5 \mathrm{~cm}$ and 0.5 $\mathrm{cm} \times 0.7 \mathrm{~cm}-0.7 \mathrm{~cm} \times 1 \mathrm{~cm}$, scattered discrete and localized distributions. The patient was differentially

diagnosed with secondary syphilis with syphilitic roseola, pityriasis rosea and palmoplantar psoriasis. To confirm the diagnosis, a serological examination was carried out on June $10^{\text {th }} 2020$, Venereal disease research laboratory test (VDRL) examination with reactive results with a titer of 1:32 and reactive treponema pallidum hemagglutination assay (TPHA) with a TPHA titer of 1:2560. He was given a single dose of intramuscular (IM) injection of benzathine penicillin $G 2.4$ million international units (IU) and education on further follow up for VDRL laboratory test.

Conclusion: A case of secondary syphilis with manifestations of syphilitic roseola has been reported in an 18-year-old teenager. The patient's has a generally good prognosis because in general the patient's condition is good, but considering the patient is still a teenager, it is possible to have irresponsible sexual relations later in life.
\end{abstract}

Keywords: infection, syphilis, adolescents, therapy.

Cite This Article: Priyadarshini, I.A.U., Wijaya, E., Puspawati, N.M.D. 2021. Sifilis sekunder pada seorang remaja perempuan: laporan kasus. Intisari Sains Medis 12(2): 728-735. D01: 10.15562/ism.v12i2.1078

\section{ABSTRAK}

Pendahuluan: Siflis merupakan salah satu penyakit infeksi menular seksual yang sering ditemukan. Sifilis dapat berbentuk akut hingga kronis. Sifilis disebabkan oleh parasit Treponema pallidum (T. pallidum). Menular melalui kontak seksual dan darah. Pada kasus ini dilaporkan sebuah kasus siflis sekunder pada remaja perempuan.

Laporan kasus: remaja perempuan 18 tahun datang dengan keluhan bercak-bercak kemerahan pada telapak tangan dan telapak kaki, dengan riwayat luka pada daerah kemaluan tidak nyeri dan tidak berbau kemudian sembuh sendiri sehingga tidak dilakukan pengobatan. Riwayat kontak seksual positif kurang lebih satu minggu sebelum pasien datang melakukan pemeriksaan. Pada status dermatologi, lokasi palmar dan plantar dekstra et sinistra ditemukan makula eritema, berbentuk bulat hingga geografika dengan ukuran diameter $0,5 \mathrm{~cm}-1,5 \mathrm{~cm}$ dan $0,5 \mathrm{~cm} \times 0,7$ $\mathrm{cm}-0,7 \mathrm{~cm} \times 1 \mathrm{~cm}$, tersebar diskret dan distribusi lokalisata. Pasien didiagnosis banding dengan siflis sekunder dengan roseola sifilitika, pitiriasis rosea dan palmoplantar psoriasis. Untuk menegakkan diagnosis dilakukan pemeriksaan serologis pada tanggal 10 Juni 2020 yakni pemeriksaan VDRL dengan hasil reaktif dengan titer 1:32 dan TPHA reaktif dengan titer TPHA 1:2560. Diberikan terapi injeksi benzatin penisilin $G$ 2,4 juta international unit (IU) intramuskular (IM) dosis tunggal dan edukasi pemantauan pengobatan yang akan dilakukan yakni pemeriksaan VDRL ulang pada bulan ke-1 setelah terapi.

Simpulan: Telah dilaporkan satu kasus siflis sekunder dengan manifestasi roseola sifilitika pada remaja berusia 18 tahun. Prognosis pasien adalah dubia ad bonam karena pada umumnya kondisi pasien 
baik, namun mengingat pasien masih remaja, ada yang tidak bertanggung jawab di kemudian hari. kemungkinan untuk melakukan hubungan seksual

Kata kunci: infeksi, sifilis, remaja, terapi.

Sitasi Artikel ini: Priyadarshini, I.A.U., Wijaya, E., Puspawati, N.M.D. 2021. Sifilis sekunder pada seorang remaja perempuan: Iaporan kasus. Intisari Sains Medis 12(2): 728-735. D0I: 10.15562/ism.v12i2.1078

\section{PENDAHULUAN}

Sifilis merupakan salah satu penyakit infeksi menular seksual yang sering ditemukan. Sifilis dapat berbentuk akut hingga kronis. Sifilis disebabkan oleh parasit Treponema pallidum (T. pallidum). Sifilis dapat dibedakan menjadi beberapa stadium sesuai dengan perjalanan penyakit. ${ }^{1}$ Dalam perjalanannya, sifilis dapat menyerang hampir seluruh organ, manifestasi klinisnya beragam sehingga sering disebut sebagai the great imitator. ${ }^{2}$

Laporan World Health Organization (WHO) menyebutkan pada tahun 2018 menyebutkan diperkirakan terdapat 6 juta kasus baru sifilis di seluruh dunia. Prevalensi sifilis pada populasi kunci menurut laporan WHO pada 2018 adalah $3,2 \% \quad(0-35,2 \%)$ pada wanita pekerja seks dan 6\% (0-36,7\%) pada LSL(lelaki yang berhubungan seks dengan lelaki). ${ }^{3}$ Di Indonesia, menurut laporan Survei Terpadu Biologi dan Perilaku tahun 2011 menyatakan bahwa prevalensi sifilis adalah $25 \%$. Pada kelompok wanita penjaja seks langsung prevalensi sifilis adalah $10 \%$, pada LSL sebesar 9\%, pada penghuni lapas sebesar $5 \%$, pada pria berisiko tinggi sebesar $4 \%$, pada wanita penjaja seks tidak langsung sebesar 3\% dan pada pengguna narkoba suntik sebesar 3\%. ${ }^{1}$ Studi CDC di Amerika pada tahun 2018 menyatakan bahwa insiden sifilis primer dan sekunder pada remaja perempuan dan dewasa muda usia 15-24 tahun adalah 7,2 kasus per 100.000 perempuan. Kejadiannya pada laki-laki usia yang sama lebih tinggi yakni 28,2 kasus per 100.000 laki-laki. ${ }^{4,5}$ Laporan subdivisi Infeksi Menular Seksual (IMS) Poliklinik Kulit dan Kelamin RSUP Sanglah Denpasar pada Januari 2019-Juni 2020 mencatat 36 kasus baru sifilis, dan 4 diantaranya adalah remaja.

Menurut World Health Organization, remaja merupakan usia transisi yakni usia 10-19 tahun, sedangkan usia pemuda adalah usia 15-24 tahun. Sedangkan di Indonesia, usia remaja menurut peraturan Menteri kesehatan RI nomor 25 tahun 2014 adalah usia 10-18 tahun. Definisi remaja yang lain adalah menurut Badan Kependudukan dan Keluarga Berencana (BKKBN) yakni usia remaja adalah usia 10-24 tahun dan belum menikah. Menurut sensus penduduk, kelompok usia 10-19 tahun diperkirakan sebanyak $18 \%$ dari seluruh total populasi. Populasi ini merupakan populasi yang memiliki risiko tinggi untuk mengalami berbagai masalah kesehatan termasuk seks bebas dan kehamilan pada remaja. ${ }^{6,7}$

Penyakit menular seksual pada remaja merupakan salah satu masalah yang banyak ditemui. Terdapat beberapa faktor yang mungkin mempengaruhi tingginya kejadian infeksi menular seksual pada remaja. Remaja yang sudah melakukan hubungan seksual biasanya memiliki kecenderungan untuk berhubungan seksual dengan lebih dari satu orang. Selain itu, pengetahuan remaja yang rendah terhadap pendidikan seksual menyebabkan perilaku seksual yang berisiko. Faktor lain adalah adanya kemungkinan keterlambatan remaja untuk mencari pengobatan. ${ }^{8}$ Remaja dengan penyakit menular seksual juga ditemukan memiliki risiko untuk mengalami gangguan lainnya, misalnya HIV dan gangguan mental, termasuk depresi. ${ }^{9,10}$

Berikut dilaporkan satu kasus sifilis sekunder pada remaja perempuan. Kasus ini dilaporkan karena jarang terjadi dan untuk memberikan pemahaman mengenai sifilis sekunder pada remaja serta penatalaksanaan sifilis pada remaja.

\section{KASUS}

Pasien perempuan usia 18 tahun, suku Bali, warga negara Indonesia dengan nomor rekam medis 2008971 datang ke Poliklinik Kulit dan Kelamin RSUP
Sanglah Denpasar bersama dengan ibu pasien pada tanggal 10 Juni 2020 dengan keluhan bercak-bercak merah pada seluruh tubuhnya sejak 7 hari yang lalu.

Pasien mengeluhkan bercak-bercak merah yang terjadi pada telapak tangan dan telapak kaki. Bercak awalnya tidak disadari pasien namun semakin lama semakin membesar. Pasien tidak mengeluhkan adanya gatal atau perih. Pasien juga tidak mengeluh adanya kehilangan sensasi pada bercak. Bercak tidak diawali oleh lenting atau lepuh sebelumnya.

Riwayat keluhan yang serupa sebelumnya disangkal oleh pasien. Pasien pernah mengalami luka di sekitar kemaluannya yang tidak nyeri dan tidak bernanah beberapa bulan lalu. Pasien tidak mengobatinya karena pasien tidak merasa nyeri. Luka kemudian sembuh sendiri tanpa disadari pasien. Pasien tidak mengeluhkan adanya bentol-bentol di bagian kemaluan pasien. Tidak ada keluhan rambut rontok, kebotakan, kelainan kuku atau kelainan pada rongga mulut pasien.

Pasien tidak mengeluhkan adanya penurunan berat badan yang bermakna. Pasien tidak mengeluhkan demam, diare dan batuk lama. Pasien juga tidak memiliki riwayat penyakit sistemik lainnya seperti diabetes melitus, gangguan jantung, asma, hipertensi atau penyakit sistemik lainnya.

Pasien belum pernah berobat untuk keluhannya ini. Riwayat penggunaan obat-obat warung yang dikonsumsi, penggunaan krim atau salep serta obatobatan tradisional disangkal. Riwayat alergi makanan dan obat-obatan disangkal. Riwayat keluhan serupa dalam keluarga disangkal.

Pasien belum menikah. Pasien adalah seorang pelajar kelas 3 SMA di salah satu sekolah negeri. Pasien saat ini tinggal bersama kedua orang tuanya dan 1 orang adik laki-laki yg berumur 5 tahun. Ayah pasien sehari-hari bekerja sebagai 
pegawai PNS, dan ibu pasien memiliki toko kelontong sambil mengasuh adiknya. Pasien mengaku sudah pernah 2 kali berpacaran dan pasien mengatakan pertama kali melakukan hubungan seksual dengan pacar sebelumnya. Pasien berpacaran dengan pacar pertamanya selama 1 tahun, dan pertama kali melakukan hubungan seksual umur 17 tahun. Pacar pertama pasien seorang mahasiswa di salah satu universitas swasta. Pasien tidak mengetahui riwayat kesehatan pacarnya. Pacar kedua pasien seorang pelajar SMA yang satu sekolah dengan pasien. Pasien sudah berpacaran selama 3 bulan dan pasien mengaku sudah berhubungan seksual dengan pacar keduanya. Pasien mengatakan terakhir berhubungan seksual 1 minggu sebelum datang ke rumah sakit. Pada saat melakukan hubungan seksual, pasien tidak pernah menggunakan kondom. Pasien tidak pernah melakukan hubungan dengan berganti-ganti pasangan selain dengan pacar. Pasien juga tidak pernah melakukan hubungan dengan pekerja seksual. Pasien tidak mengetahui aktivitas seksual pacarnya. Pacar pasien sudah pernah berpacaran dengan orang lain sebelumnya. Riwayat konsumsi alkohol, merokok, penggunaan narkotika dan obat-obat terlarang disangkal oleh pasien. Pasien juga tidak memiliki tato.

Pada pemeriksaan fisik generalis didapati keadaan umum pasien baik, tampak sakit ringan dan kesadaran kompos mentis. Pada pemeriksaan tanda vital didapati tekanan darah 110/70 mmHg, denyut nadi $80 \mathrm{kali} / \mathrm{menit}$ respirasi $18 \mathrm{kali} /$ menit, dan temperatur aksila $36,7^{\circ} \mathrm{C}$. Berat badan pasien adalah $54 \mathrm{~kg}$ dengan tinggi badan $152 \mathrm{~cm}$ dan indeks massa tubuh (IMT) 23,37. Pada pemeriksaan kepala leher tidak didapati gambaran moth-eaten alopecia dan corona veneris (Gambar 1C). Tidak didapati konjungtiva anemis atau sklera ikterik. Pemeriksaan telinga hidung tenggorokan tampak tenang dan tidak didapati kelainan bermakna. Tidak ada pembesaran kelenjar getah bening di area leher, ketiak atau selangkangan pasien (Gambar 1A dan 1B). Pada pemeriksaan jantung dan paru pasien tidak ditemukan kelainan. Pada pemeriksaan abdomen ditemukan bising usus normal, tidak ada distensi dan
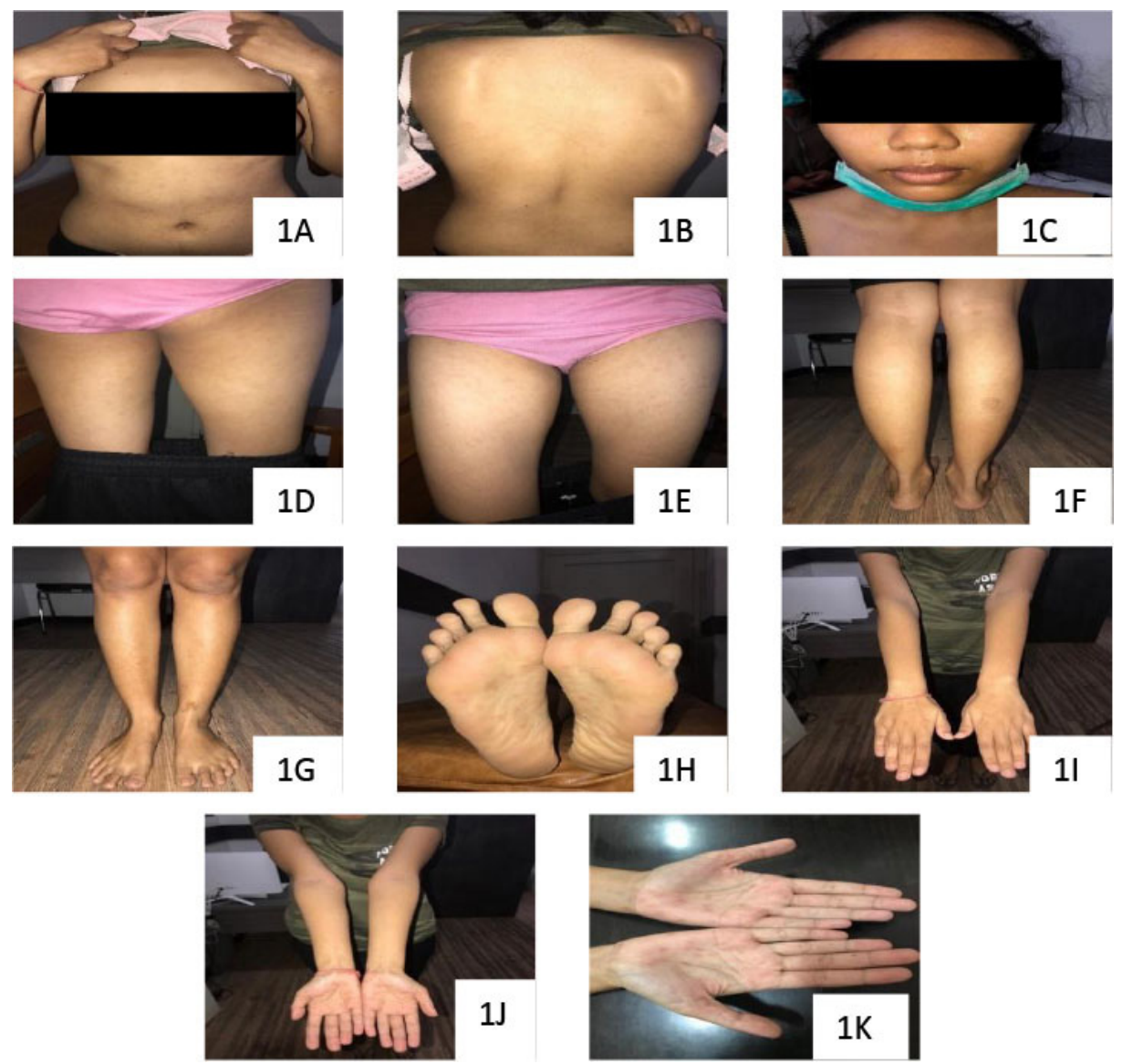

Gambar 1. Foto klinis dari pasien; pada gambar $1 \mathrm{H}$ dan $1 \mathrm{~K}$ tampak makula eritema.

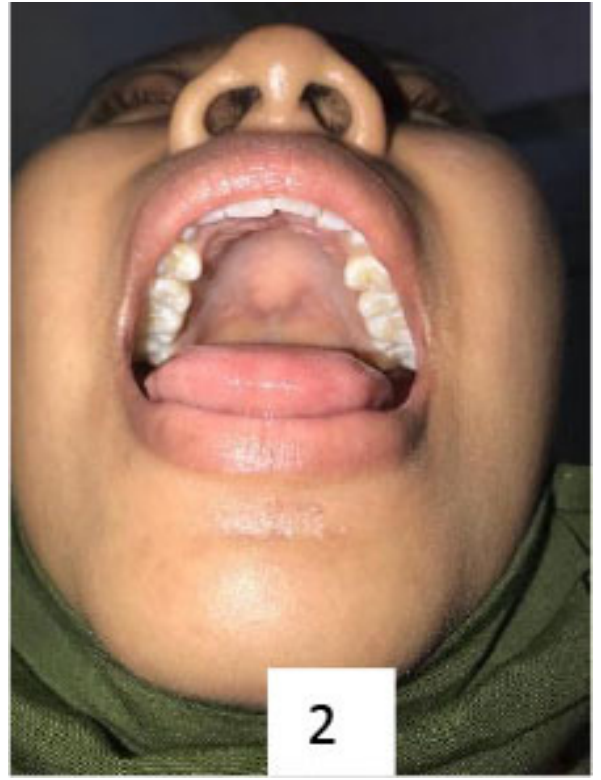

Gambar 2. Tidak tampak kelainan pada rongga oral pasien.

organomegali. Keempat ekstremitas tidak edema dan teraba hangat.

Pada status dermatologi, lokasi palmar

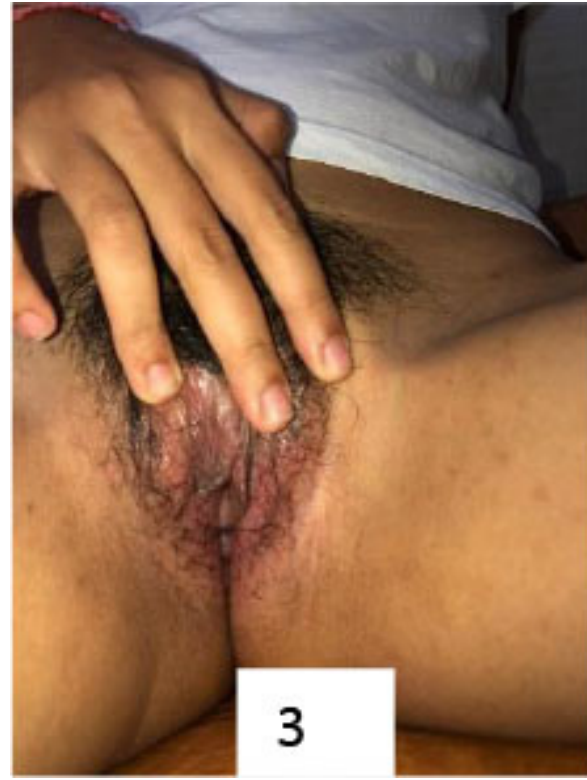

Gambar 3. Tidak tampak kelainan pada area genital pasien.

dan plantar dekstra et sinistra ditemukan makula eritema, berbentuk bulat hingga geografika dengan ukuran diameter 0,5 

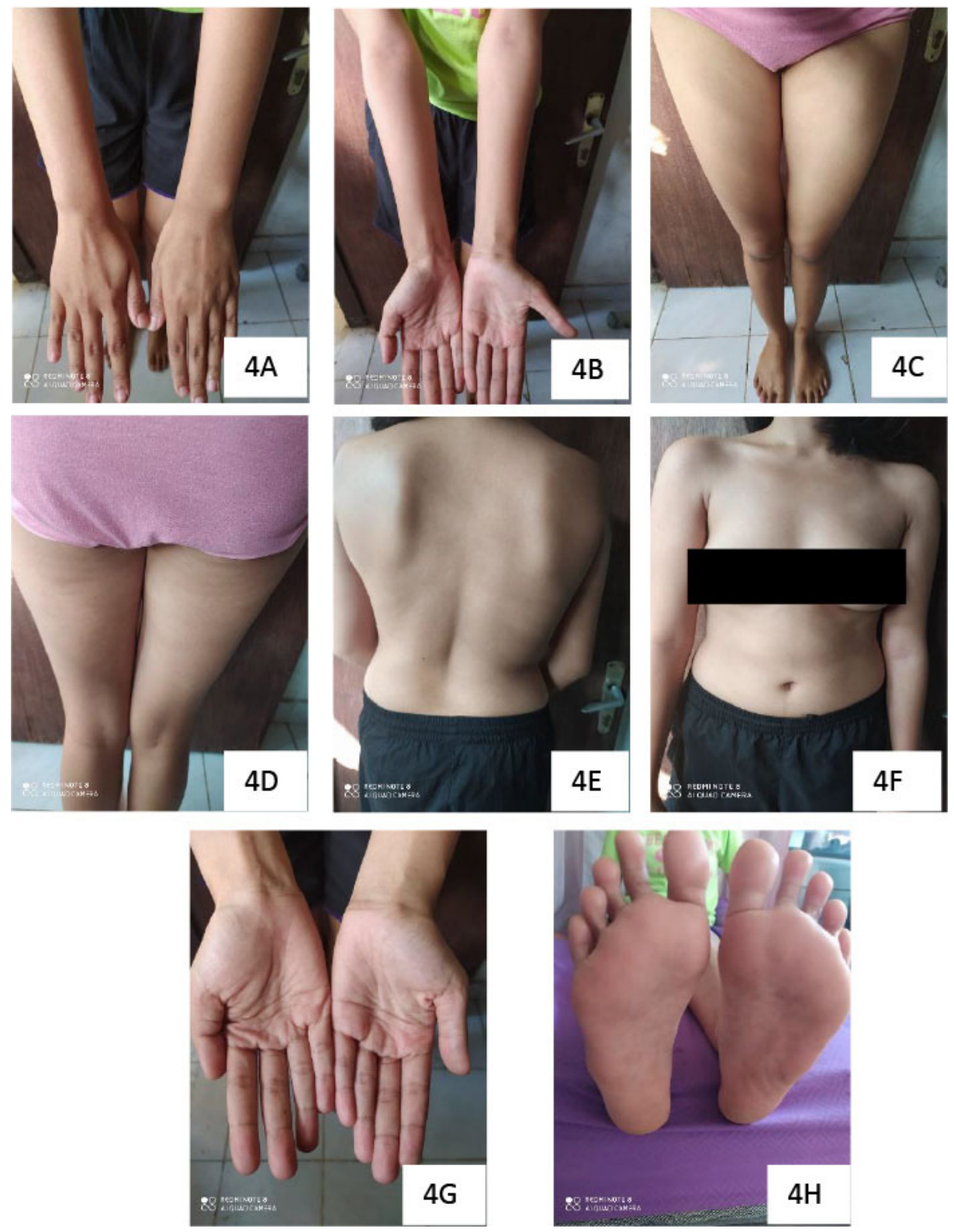

Gambar 4. Tidak tampak gambaran roseola sifilitika pada seluruh tubuh pasien.

$\mathrm{cm}-1,5 \mathrm{~cm}$ dan $0,5 \mathrm{~cm} \times 0,7 \mathrm{~cm}-0,7 \mathrm{~cm}$ x $1 \mathrm{~cm}$, tersebar diskret dan distribusi lokalisata (Gambar 1H dan 1K). Tidak ditemukan adanya kelainan pada area femoral (Gambar 1D dan 1E), cruris (Gambar 1F dan 1G), ekstremitas superior (Gambar 1I dan 1J), rongga mulut (Gambar 2), dan genital (Gambar 3).

Pasien didiagnosis banding dengan sifilis sekunder dengan roseola sifilitika, pitiriasis rosea dan palmoplantar psoriasis. Untuk menegakkan diagnosis dilakukan pemeriksaan serologis pada tanggal 10 Juni 2020 yakni pemeriksaan VDRL dengan hasil reaktif dengan titer 1:32 dan TPHA reaktif dengan titer TPHA 1:2560.
Pasien didiagnosis kerja dengan sifilis sekunder dengan gambaran roseola sifilitika pada remaja. Pasien diberikan injeksi benzatin penisilin G 2,4 juta international unit (IU) intramuskular (IM) dosis tunggal. Sebelum disuntikkan, dilakukan skin test terlebih dahulu untuk memastikan tidak ada alergi pada pasien. Pasien diberikan edukasi mengenai penyakitnya, penyebab, terapi, kontrol selanjutnya, dan pentingnya mengobati pasangannya. Pasien juga diberikan edukasi mengenai pemantauan pengobatan yang akan dilakukan yakni pemeriksaan VDRL ulang pada bulan ke-1 setelah terapi. Pemeriksaan juga diulang pada bulan ke-3, 6, dan 12 pasca terapi. Pasien juga diedukasi mengenai adanya kemungkinan reaksi setelah penyuntikan yakni reaksi Jarisch-Herxheimer. Pasien diedukasi mengenai pentingnya abstinensia seksual selama pengobatan dan menyarankan pasangan pasien untuk diperiksa saat kontrol. Pasien disarankan untuk konsultasi ke bagian psikiatri namun pasien menolak.

\section{PENGAMATAN LANJUTAN I (Hari ke-31, 9 Juli 2020)}

Pasien datang untuk kontrol dan membawa hasil pemeriksaan laboratorium. Keluhan bercak di telapak tangan dan telapak kaki pasien sudah berkurang dan menghilang di beberapa tempat. Pada pemeriksaan fisik didapati keadaan umum baik, status generalisata pasien dalam batas normal. Pada pemeriksaan dermatologi tidak didapatkan efloresensi (Gambar 4A-4H).

Pasien melakukan pemeriksaan VDRL pada tanggal 9 Juli 2020 dan didapatkan penurunan titer VDRL menjadi 1:16. Diagnosis dari bagian kulit dan kelamin adalah follow up sifilis sekunder. Pasien diberikan KIE mengenai penyakit, terapi, kontrol selanjutnya, dan untuk pasien disarankan kontrol pemeriksaan VDRL bulan ke-3 setelah terapi, kemudian diulang kembali pada bulan ke-6, dan ke12.

\section{PEMBAHASAN}

Studi menemukan bahwa pada $16-30 \%$ orang yang kontak dengan lesi aktif sifilis mengalami sifilis dalam 30 hari. Selain kontak genitalia, sifilis juga dapat menular dengan oral seksual atau dengan anal, terutama pada male sex with male (MSM). Pada negara miskin dan berkembang, masih dapat ditemukan risiko penularan sifilis melalui transfusi darah. Bentuk transmisi sifilis lain yang lebih jarang ditemukan adalah melalui perlukaan dari instrumen medis yang terkontaminasi atau saat membuat tato. Sifilis kongenital juga dapat terjadi ketika terjadi transversi spirochaeta melalui plasenta dari ibu yang terinfeksi kepada fetus. Transmisi vertikal dari ibu ke anak juga dapat terjadi melalui kontak langsung kulit ke kulit pada saat persalinan pervaginam. ${ }^{11,12}$

Setelah terjadinya kontak kulit pada 
pasien dengan lesi sifilis aktif, terjadi penetrasi T. pallidum melalui mikrolesi yang muncul terutama setelah hubungan seksual. Penetrasi T. pallidum juga dapat pada mukosa yang intak. Setelah terjadinya penetrasi, T. pallidum akan bergerak menuju kelenjar limfatik regional dan kemudian mengalami penyebaran secara hematogen, dan terdeposit pada organ-organ lain. Manifestasi lokal pada sifilis primer terjadi akibat respons imun lokal pada lokasi penetrasi T. pallidum dan menyebabkan ulkus. Manifestasi sistem dapat terjadi akibat terbentuknya kompleks imun dan terdisposisi pada berbagai organ. Manifestasi sistemik terutama terjadi akibat ketidakmampuan sistem imun humoral dan seluler untuk mengatasi T. pallidum. ${ }^{13-15}$

Pasien adalah seorang remaja perempuan dengan keluhan bercak kecoklatan yang didiagnosis dengan ruam sifilitika sebagai manifestasi sifilis sekunder. Faktor risiko pada pasien adalah adanya riwayat hubungan seksual tanpa pengaman beberapa waktu sebelum keluhan terjadi. Tidak ada faktor risiko lain pada pasien. Studi di RSUP Sanglah menemukan bahwa pasien sifilis yang datang ke poli umumnya adalah laki-laki, kelompok usia 15-24 tahun dan datang dengan keluhan sifilis sekunder. ${ }^{16}$ Pasien dalam hal ini merupakan kelompok usia dan keluhan yang sering ditemukan namun terjadi pada perempuan.

Terdapat beberapa stadium klinis sifilis berdasarkan manifestasi klinis dan perjalanan penyakitnya. Secara umum stadium klinis dapat dibedakan menjadi empat yakni sifilis primer, sifilis sekunder, sifilis laten dan sifilis tersier. Sifilis primer ditandai dengan lesi ulkus yang khas pada tempat terjadinya inokulasi. Selanjutnya terjadi perkembangan manifestasi klinis menjadi sifilis sekunder yang ditandai dengan rumah kulit mukokutanoeus dan limfadenopati. Pada kasus yang tidak ditangani dengan baik, maka pasien berkembang menjadi sifilis laten. Pada stadium ini biasanya tidak ditemukan gejala pada pasien. Pasien biasanya terdiagnosis sifilis melalui pemeriksaan serologis. Tahap akhir merupakan sifilis tersier yang ditandai dengan adanya gumma atau neurosifilis. ${ }^{11,12,17}$

Lesi sifilis primer ditandai dengan lesi khas berupa chancre. Chancre merupakan lesi ulserasi tidak nyeri dengan dasar datar, batas tegas dan tidak nyeri. Lesi ini terjadi akibat respons imun lokal pada daerah terjadinya inokulasi. Chancre biasanya berukuran 0,5 hingga $2 \mathrm{~cm}$ dalam diameter. Lokasi lesi yang paling sering merupakan daerah genitalia, yakni penis pada laki-laki dan labia dan serviks pada perempuan. Pada laki-laki LSL, dapat pula ditemukan lesi primer pada kanal anal dan rongga oral. Pada $80 \%$ kasus dapat ditemukan pula limfadenopati inguinal nonsupuratif yang tidak nyeri. Umumnya hanya terdapat satu lesi saja, namun pada kasus pasien dengan HIV dapat ditemukan lesi multipel. Lesi primer biasanya tidak menimbulkan gejala yang mengganggu hingga pasien jarang menyadarinya. Lesi primer ini mulai terbentuk dalam 3 minggu saat pertama kali terpapar dengan masa inkubasi selama 10-90 hari. Lesi primer ini kemudian sembuh spontan dalam 4 hingga 6 minggu, namun dalam 15\% kasus masih dapat ditemukan ulkus saat terjadi manifestasi sifilis sekunder. ${ }^{11-15,17}$

Selanjutnya, bila pasien tidak mendapatkan terapi yang adekuat, maka akan terjadi diseminasi sistemik spirochaeta yang terjadi dalam 6 minggu hingga 6 bulan sejak terbentuknya lesi primer. Kondisi inilah yang menyebabkan adanya manifestasi klinis sifilis sekunder. Manifestasi klinis pada lesi sifilis sekunder biasanya berupa gejala konstitusi seperti nyeri tenggorokan, mialgia, malaise, dan penurunan berat badan. ${ }^{14-16}$

Lesi sifilis sekunder yang dapat ditemukan seperti corona veneris atau Crown of Venus, Biette's collorette, motheaten alopecia, dan mucous patch. Namun, lesi sifilis sekunder yang paling sering ditemukan adalah roseola sifilitika. ${ }^{11-15,17}$

Ruam sifilis atau roseola sifilitika merupakan ruam makulopapular, tidak gatal, berwarna pucat hingga merah tembaga. Ruam ini awalnya muncul di telapak batang tubuh dan ekstremitas proksimal hingga menyebar ke seluruh tubuh termasuk telapak tangan dan kaki, seperti lesi target. Selain itu, dapat pula ditemukan bercak-bercak berwarna perak sampai abu-abu pada lesi erosi di mukosa genital, anal dan/atau oral. Dapat juga ditemukan limfadenopati generalisata. Manifestasi sifilis sekunder lainnya adalah kondiloma lata. Kondiloma lata adalah plak berwarna abu-abu pada daerah yang lembab, umumnya pada daerah intertriginosa, seperti labia mayora dan minora. ${ }^{18}$

Pada dasarnya gambaran manifestasi klinis sifilis sekunder pada remaja sama dengan pada orang dewasa. ${ }^{19}$ Laporan kasus di Amerika melaporkan kejadian sifilis sekunder pada remaja perempuan usia 15 tahun dengan manifestasi klinis berupa ruam yang tidak gatal terutama pada telapak tangan dan telapak kaki. ${ }^{20}$ Bahkan, sebuah laporan kasus sifilis sekunder pada anak laki-laki usia 10 tahun menunjukkan manifestasi klinis yang sama dengan orang dewasa, misalnya kondiloma lata, makula hiperpigmentasi pada telapak kaki dan makula atrofik pada telapak tangan. ${ }^{21}$

Pada pasien ditemukan adanya lesi berwarna tembaga yang tersebar di seluruh tubuh hingga telapak tangan dan telapak kaki. Gambaran lesi menyerupai lesi target di beberapa tempat. Tidak ditemukan adanya limfadenopati pada pasien. Selain itu juga tidak ditemukan adanya manifestasi sifilis sekunder lainnya seperti Biette's collorette, moth-eaten alopecia, mucous patch, atau kondiloma lata.

Metode diagnostik yang dilakukan untuk menegakkan diagnosis sifilis adalah dengan mengidentifikasi T. pallidum. Pemeriksaan kultur tidak dapat dilakukan karena T. pallidum tidak dapat tumbuh dalam jangka waktu yang lama pada kondisi in vitro. Pemeriksaan yang dapat dilakukan untuk mendiagnosis sifilis dilakukan dengan deteksi langsung dan tes serologis. Deteksi langsung dilakukan dengan DFM, direct fluorescent antibody (DFA), polymerase chain reaction (PCR). Pemeriksaan yang digunakan sebagai dengan diagnosis pasti sifilis dilakukan dengan DFM (dark-field microscopy) atau DFA, namun pemeriksaan ini tidak dilakukan dalam praktek klinis karena tidak tersedia secara luas dan membutuhkan tenaga laboratorium terlatih. ${ }^{1,12,13}$

Terdapat dua jenis pemeriksaan serologis yang banyak digunakan guna pemeriksaan sifilis. Pemeriksaan pertama adalah pemeriksaan non treponemal seperti pemeriksaan Venereal Disease 
Research Laboratory (VDRL) dan Rapid Plasma Reagen (RPR) yang merupakan tes antibodi non spesifik. Tes ini mendeteksi adanya imunoglobulin yang adalah antibodi terhadap bahan-bahan lipid sel-sel T. pallidum yang hancur seperti cardiolipin, kolesterol dan lesitin. Jenis pemeriksaan ini memiliki spesifisitas yang tinggi yakni 97-99\%. Namun demikian, pemeriksaan ini memiliki risiko negatif palsu, yakni saat terjadinya reaksi prozon. Reaksi prozon terjadi ketika tidak terjadi reaksi aglutinasi karena antibodi non reaktif sangat tinggi. Reaksi prozon dapat dicegah dengan melakukan hingga 16 dilusi pada sampel. Hasil positif palsu dapat terjadi pada kondisi infeksi lain, keganasan, penggunaan narkoba, kehamilan, penyakit autoimun dan penuaan. Hasil pemeriksaan dapat ditampilkan dalam bentuk kualitatif dan kuantitatif. Pemeriksaan ini dapat digunakan sebagai metode skrining, untuk mendeteksi adanya reinfeksi yang bersifat aktif dan untuk memantau keberhasilan terapi. ${ }^{1,22}$

Metode pemeriksaan kedua adalah pemeriksaan treponemal spesifik yang dapat digunakan untuk menegakkan sifilis. Jenis pemeriksaan yang menggunakan teknik ini adalah tes TPHA (Treponema Pallidum Haemagglutination Assay), TP Rapid (Treponema Pallidum Rapid), TP-PA (Treponema Pallidum Particle Agglutination Assay), FTAABS (Fluorescent Treponemal Antibody Absorption). Pemeriksaan ini mendeteksi antibodi yang spesifik terhadap treponema dengan sensitivitas dan spesifisitas yang cukup tinggi, yakni 97-99\%. Pemeriksaan ini dapat mendeteksi antibodi dalam jumlah yang kecil. Pemeriksaan ini tetap menunjukkan hasil yang positif walaupun pasien telah berhasil diterapi dengan efektif, sehingga pemeriksaan ini tidak dapat digunakan namun sebagai modalitas monitoring terapi. Pemeriksaan ini juga tidak dapat membedakan infeksi oleh T. pallidum dan infeksi Treponema lainya., ${ }^{1,22}$

Kedua metode pemeriksaan ini dibutuhkan untuk menegakkan diagnosis sifilis. Pemeriksaan awal dilakukan dengan pemeriksaan non treponemal. Pasien dengan hasil pemeriksaan non treponemal reaktif, maka harus dilakukan pemeriksaan konfirmasi dengan pemeriksaan treponemal. Pasien dengan hasil pemeriksaan non treponemal reaktif pun tidak serta merta menyingkirkan diagnosis sifilis karena pada pasien dapat ditemukan adanya hasil pemeriksaan non treponemal negatif dalam 4 minggu sejak lesi primer muncul. ${ }^{1}$

Diagnosis banding pada pasien sesuai dengan gambaran klinis adalah pitiriasis rosea dan palmoplantar psoriasis. Gambaran klinis pasien pitiriasis rosea biasanya terjadi pada anak-anak dan dewasa usia 10-40 tahun. Pasien biasanya mengalami demam, sefalgia, mialgia, malaise, dan hilangnya nafsu makan. Pasien dengan pitiriasis rosea biasanya ditandai dengan adanya lesi primer yang dikenal dengan herald patch. Lesi sekunder kemudian biasanya akan timbul dalam 5 hingga 15 hari. Lesi kulit biasanya terjadi pada lengan, leher, dada, perut, dan telapak tangan dan telapak kaki disertai gatal dan berbentuk seperti cemara terbalik. Sampai saat ini belum diketahui penyebabnya, namun studi menemukan bahwa pitiriasis rosea dihubungkan dengan cuaca, virus dan penggunaan obat-obatan. ${ }^{23}$

Diagnosis banding lain adalah palmoplantar psoriasis. Palmoplantar psoriasis merupakan penyakit non infeksi, yang merupakan salah satu manifestasi klinis dari psoriasis. Penyakit ini terutama terjadi pada telapak tangan dan kaki. Manifestasi penyakit ini berupa lesi kemerahan berkonfluens tanpa bentuk plak yang jelas. Pada beberapa kasus dapat ditemukan plak dengan skuama pada telapak tangan dan kaki. Lesi yang terbentuk biasanya berwarna kemerahan dan berbatas tegas. ${ }^{12}$

Penatalaksanaan sifilis menurut panduan WHO membagi atas 3 kategori, yakni sifilis dini, sifilis lama dan sifilis kongenital. Dalam kepentingan pengobatan, sifilis dini termasuk diantaranya adalah sifilis primer, sifilis sekunder dan sifilis laten dengan durasi kurang dari 2 tahun. Sifilis lama adalah sifilis dengan infeksi lebih dari 2 tahun. Pengobatan utama pada sifilis dini adalah injeksi benzatin penisilin G 2,4 juta unit intramuskular 1 kali. Bila tidak ada benzatin penisilin $G$ maka pilihan lainnya adalah prokain penisilin G 1,2 juta unit intramuskular setiap hari selama 10-14 hari. Pada pasien yang tidak dapat menggunakan penilisin karena alergi atau tidak adanya ketersediaan, maka dapat digantikan dengan doksisiklin 2 kali 100 mg selama 14 hari atau injeksi seftriakson intramuskuler 1 gram setiap hari selama 10-14 hari. Pada kondisi tertentu, pilihan pengobatan juga dapat diberikan azitromisin 2 gram dosis tunggal. Pada ibu hamil, rekomendasi terapi sifilis pada dasarnya sama, namun tidak diberikan alternatif doksisiklin tetapi eritromisin 4 kali 500 mg per hari selama 14 hari. $^{24}$

Panduan terapi sifilis pada pasien di Indonesia hanya dibedakan menjadi 2 yakni pasien dengan sifilis primersekunder dan pasien sifilis laten. Pada pasien sifilis primer dan sekunder, pasien ditatalaksana dengan benzatin benzilpenisilin G 2,4 juta unit dosis tunggal intramuskular dengan alternatif doksisiklin 2 kali $100 \mathrm{mg}$ PO selama 30 hari atau eritromisin 4 kali $500 \mathrm{mg}$ PO selama 14 hari. Pasien dengan sifilis laten diberikan benzatin benzilpenisilin 2,4 juta unit intramuskular selama 3 minggu berturut-turut dan alternatif doksisiklin 2 kali 100 mg PO selama minimal 30 hari atau seftriakson $1000 \mathrm{mg}$ intramuskular selama 10 hari atau eritromisin 4 kali 500 mg PO selama minimal 30 hari. $^{1}$

Pada dasarnya tidak ada perbedaan tata laksana yang diberikan pada remaja yang mengalami sifilis sekunder bila dibandingkan dengan pasien dewasa. Panduan WHO dan Indonesia hanya membedakan terapi sifilis berdasarkan stadium dan apakah pasiennya hamil atau tidak. ${ }^{1,24}$ Laporan kasus juga menyebutkan menggunakan terapi farmakologis yang sama pada pasien remaja dengan sifilis. ${ }^{19-21}$

Pada kasus pasien mendapatkan benzatin penisilin G 2,4 juta unit dosis tunggal, diberikan secara intramuskular. Sebelum dilakukan penyuntikan dilakukan skin test terlebih dahulu untuk memastikan tidak ada alergi pada pasien. Pemberian benzatin penisilin G 2,4 juta efektif untuk penatalaksanaan pasien dengan sifilis, didukung oleh banyak studi. ${ }^{25}$

Bagian paling penting dalam penatalaksanaan sifilis pada remaja adalah konseling dan edukasi. ${ }^{26}$ The US Preventive Services Task Force memberikan rekomendasi untuk melakukan terapi berbasis perilaku pada pasien remaja 
dengan penyakit menular seksual untuk mencegah perilaku seksual yang tidak aman. Pendekatan pada orang juga perlu dilakukan untuk memberikan penjelasan pada orang tua. ${ }^{28}$ Pada prakteknya, pasien dapat dikirimkan ke bagian psikiatri untuk mendapatkan terapi. Konsul pada psikiatri juga dapat dilakukan mengingat bahwa terdapat kejadian gangguan mental pada remaja dengan penyakit infeksi menular seksual, terutama depresi. ${ }^{9}$

Terdapat beberapa komplikasi yang mungkin terjadi pada pasien. Bila penatalaksanaan tidak selesaikan, maka akan ada kemungkinan untuk terjadinya perkembangan klinis sifilis pada pasien. Komplikasi yang mungkin terjadi yang mungkin secara tidak langsung berhubungan dengan infeksi treponema itu sendiri adalah komplikasi yang terjadi akibat hubungan seksual yang tidak aman. Kehamilan yang tidak diinginkan, termasuk risiko sifilis kongenital pada anak yang dilahirkan merupakan salah satu risiko yang muncul pada pasien. Selain itu, pasien dengan infeksi menular seksual terbukti memiliki risiko untuk mengalami HIV yang lebih tinggi. ${ }^{9,10}$

Pada kasus, prognosis pasien adalah dubia ad bonam. Pada pasien ditemukan adanya perbaikan lesi dan penurunan titer pada pemeriksaan. Namun demikian, pada pasien harus dilakukan edukasi mengenai perilaku seksual yang aman dan terapi pada pasangannya. Mengingat bahwa pasien adalah pasien remaja, akan ada kemungkinan untuk pasien melakukan hubungan seksual yang berisiko selanjutnya.

\section{SIMPULAN}

Telah dilaporkan satu kasus sifilis sekunder dengan manifestasi roseola sifilitika pada remaja berusia 18 tahun. Diagnosis ditegakkan berdasarkan anamnesis, pemeriksaan fisik dan pemeriksaan penunjang. Pada pasien didapatkan faktor resiko hubungan seksual tanpa pengaman. Infeksi menular seksual merupakan salah satu permasalahan pada remaja yang terjadi akibat keingintahuan remaja dan minat seksual yang tinggi tanpa adanya pengetahuan yang baik tentang perilaku seksual. Pasien mendapatkan terapi benzatin penisilin 2,4 juta unit IM dosis tunggal dan ditemukan perbaikan secara klinis dan laboratoris. Prognosis pasien adalah dubia ad bonam karena pada umumnya kondisi pasien baik, namun mengingat pasien masih remaja, ada kemungkinan untuk melakukan hubungan seksual yang tidak bertanggung jawab di kemudian hari.

\section{KONFLIK KEPENTINGAN}

Penulis menyatakan tidak terdapat konflik kepentingan terkait publikasi dari laporan kasus ini.

\section{PENDANAAN}

Laporan kasus ini tidak mendapat pendanaan dari lembaga pemerintah maupun lembaga swasta lain.

\section{ETIKA DALAM PUBLIKASI}

Pasien telah menandatangani lembar informed consent terkait publikasi dari foto klinis dan data medis dengan tetap menjaga asas kerahasian dari identitas pasien untuk kepentingan publikasi pada jurnal ilmiah kedokteran.

\section{KONTRIBUSI PENULIS}

Ida Ayu Uttari Priyadarshini bertanggung jawab terhadap follow up dari kasus serta penulisan draft laporan kasus. Ni Made Dwi Puspawati bertindak dalam supervisi kasus dan turut serta dalam menuntun penulisan draft laporan kasus.

\section{DAFTAR PUSTAKA}

1. Majid N, Bollen L, Morineau G, Daily SF, Mustikawati DE, Agus N, et al. Syphilis among female sex workers in Indonesia: need and opportunity for intervention. Sex Transm Infect. 2010;86(5):377-83. Available from: http://dx.doi.org/10.1136/sti.2009.041269

2. Çakmak SK, Tamer E, Karadağ AS, Waugh M. Syphilis: A great imitator. Clin Dermatol. 2019;37(3):182-91. Available from: http:// dx.doi.org/10.1016/j.clindermatol.2019.01.007

3. Prasad V, Schwerdtfeger U, El-Awa F, Bettcher D, da Costa e Silva V, et al. Closing the door on illicit tobacco trade, opens the way to better tobacco control. East Mediterr Heal J. 2015;21(6):379-80. Available from: http:// dx.doi.org/10.26719/2015.21.6.379

4. Sexually Transmitted Disease (STD) Prevention [Internet]. PsycEXTRA Dataset. Test accounts; 2000. Available from: http://dx.doi.org/10.1037/ e313002005-001

5. Kojima N, Klausner JD. An Update on the Global Epidemiology of Syphilis. Curr Epidemiol reports. 2018/02/19. 2018;5(1):24-
38. Available from: https://pubmed.ncbi.nlm. nih.gov/30116697

6. Lestyoningsih IH. Implementasi model kesehatan reproduksi berbasis masalah pada remaja putri di indonesia tahun 2018. J Berk Kesehat. 2018;4(2):47. Available from: http:// dx.doi.org/10.20527/jbk.v4i2.5659

7. Shannon CL, Klausner JD. The growing epidemic of sexually transmitted infections in adolescents: a neglected population. Curr Opin Pediatr. 2018;30(1):137-43. Available from: https://pubmed.ncbi.nlm.nih.gov/29315111

8. Franjić S. Adolescent Venereal Diseases. Madridge J Immunol. 2019;3(2):95-9. Available from: http://dx.doi.org/10.18689/mjim1000122

9. Khan MR, Kaufman JS, Pence BW, Gaynes BN, Adimora AA, Weir SS, et al. Depression, sexually transmitted infection, and sexual risk behavior among young adults in the United States. Arch Pediatr Adolesc Med. 2009;163(7):644-52. Available from: https://pubmed.ncbi.nlm.nih. gov/19581548

10. Newbern EC, Anschuetz GL, Eberhart MG, Salmon ME, Brady KA, De Los Reyes A, et al. Adolescent sexually transmitted infections and risk for subsequent HIV. Am J Public Health. 2013/08/15. 2013;103(10):1874-81. Available from: https://pubmed.ncbi.nlm.nih. gov/23947325

11. Goh BT. Syphilis in adults. Sex Transm Infect. 2005;81(6):448-52. Available from: https:// pubmed.ncbi.nlm.nih.gov/16326843

12. Emerson CR. Syphilis: A Review of the Diagnosis and Treatment. Open Infect Dis J. 2009;3(1):143-7. Available from: http://dx.doi. org/10.2174/1874279301004010143

13. Koumans EH, Farley TA, Gibson JJ, Langley C, Ross MW, McFarlane M, et al. Characteristics of Persons With Syphilis in Areas of Persisting Syphilis in the United States. Sex Transm Dis. 2001;28(9):497-503. Available from: http:// dx.doi.org/10.1097/00007435-20010900000004

14. Arando M, Fernandez-Naval C, Mota-Foix M, Martinez D, Armengol P, Barberá MJ, et al. Early syphilis: risk factors and clinical manifestations focusing on HIV-positive patients. BMC Infect Dis. 2019;19(1):727. Available from: https:// pubmed.ncbi.nlm.nih.gov/31420018

15. Carlson JA, Dabiri G, Cribier B, Sell S. The immunopathobiology of syphilis: the manifestations and course of syphilis are determined by the level of delayed-type hypersensitivity. Am J Dermatopathol. 2011;33(5):433-60. Available from: https:// pubmed.ncbi.nlm.nih.gov/21694502

16. Artawan KJ, Putra IWA. Karakteristik epidemologi ibu hamil dengan infeksi human immunodeficiency virus di RSUP Sanglah Denpasar periode Januari 2014 - Desember 2017. Intisari Sains Medis. 2020;11(2):798. Available from: http://dx.doi.org/10.15562/ism. v11i2.792

17. Ghanem KG, Workowski KA. Management of Adult Syphilis. Clin Infect Dis. 2011;53(suppl_3):S110-28. Available from: http://dx.doi.org/10.1093/cid/cir701 
18. Batan NW, Puspawati D. Kondiloma lata sebagai manifestasi klinis sifilis sekunder pada kehamilan trimester kedua. Medicina (B Aires). 2019;50(2). Available from: http://dx.doi. org/10.15562/medicina.v50i2.393

19. Chinsembu KC. Sexually Transmitted Infections in Adolescents. Open Infect Dis J. 2009;3(1):107-17. Available from: http://dx.doi. org/10.2174/1874279301004010107

20. Kaufman J, Garcia B, Horrall S. Syphilis at age 15 years. Proc (Bayl Univ Med Cent). 2018;31(1):105-6. Available from: https:// pubmed.ncbi.nlm.nih.gov/29686572

21. Nisha R, Priya B, Mahalakshmi V, Murugan S. Secondary syphilis in a preadolescent boy. Indian J Paediatr Dermatology. 2019;20(3):246. Available from: http://dx.doi.org/10.4103/ijpd. ijpd_114_18
22. Brown DL, Frank JE. Diagnosis and Management of Syphilis. Am Fam Physician. 2003;68:283-90.. Available from: https:// pubmed.ncbi.nlm.nih.gov/12892348/

23. Urbina F, Das A, Sudy E. Clinical variants of pityriasis rosea. World J Clin cases. 2017;5(6):203-11. Available from: https:// pubmed.ncbi.nlm.nih.gov/28685133

24. World Health Organization. WHO Guidelines for The Treatment of Treponema pallidum (syphilis). Geneva: World Health Organization; 2016.

25. Clement ME, Okeke NL, Hicks CB. Treatment of syphilis: a systematic review. JAMA. 2014;312(18):1905-17. Available from: https:// pubmed.ncbi.nlm.nih.gov/25387188
26. Job vacancy at the European Centre for Disease Prevention and Control (ECDC). Eurosurveillance of syphilis. 2021;26(13):1-9. Available from: http://dx.doi.org/10.2807/15607917.es.2021.26.13.2104011

27. Marrazzo JM, Cates W. Interventions to prevent sexually transmitted infections, including HIV infection. Clin Infect Dis. 2011;53 Suppl 3(Suppl 3):S64-78. Available from: https:// pubmed.ncbi.nlm.nih.gov/22080271

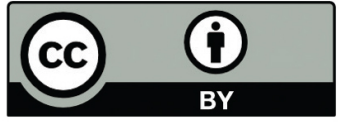

This work is licensed under a Creative Commons Attribution 